\title{
Household Food Security, Nutritional Intake, and Nutritional Status of Pregnant Women in the Central Tapanuli Regency
}

\author{
Etti Sudaryati ${ }^{1}$, Fikarwin Zuska ${ }^{2}$ iD, Herta Masthalina ${ }^{3 *}$ iD \\ ${ }^{1}$ Department of Nutrition, Faculty of Public Health, Universitas Sumatera Utara, Medan, Indonesia; ${ }^{2}$ Department of Anthropology, \\ Faculty of Public Fisip, Universitas Sumatera Utara, Medan, Indonesia; ${ }^{3}$ Department of Nutrition, Poltekkes Kemenkes Medan, \\ Medan, Indonesia
}

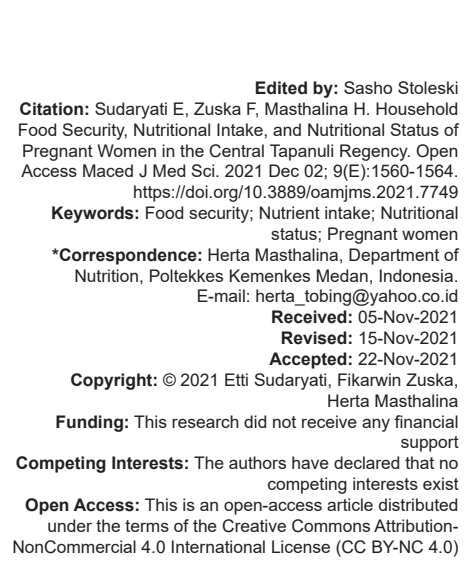

\section{Introduction}

Pregnant women are a vulnerable population in society. Malnutrition during pregnancy can have a cumulative effect on the nutritional condition of the fetus, resulting in non-optimal birth weight. Several studies that have used $2500 \mathrm{~g}$ as a birth minimum weight are associated with the risk of morbidity and mortality in newborns. Undernourished mothers cause the fetus to have impaired growth and placental function, which is reflected in the placenta's lower weight and size. Malnutrition in the mother reduces blood volume expansion, resulting in inadequate blood flowing from the heart (cardiac output). This decreases blood flow to the placenta, resulting in suboptimal placental size and decreased nutritional delivery to the fetus, leading to fetal growth retardation [1], [2].

The nutritional condition and health of the mother throughout pre-pregnancy, pregnancy, and breastfeeding are essential for the growth and development of children. The first 1000 days of life are a critical time or "window of opportunity [3]."
Chronic energy deficiency (CED), nutritional anemia, and iodine deficiency disorders (IDDs) are common nutritional disorders in pregnant women. Pregnant women with CED contribute $25-50 \%$ of intrauterine growth retardation in the fetus, and this condition is passed on from generation to generation, resulting in the child's development being less than ideal the following year [4]. According to the research in India, pregnant women with CED are associated with being underweight, stunting, and wasting in children under the age of five [5]. In line with research in Nigeria, pregnant women with poor nutritional status are 7 times more likely to have stunting, 11 times more likely to be underweight, and 12 times more likely to experience wasting than mothers who do not suffer malnutrition during pregnancy [6]. Research in Pati regency found that anemia in pregnant women was a risk factor for low birth weight (LBW) $(p=0.001)$, with the odds ratio value proving that mothers with anemia were 9 times more likely to give birth to babies with LBW than mothers who were not anemic during pregnancy [7]. According to the Pibriyanti's research, there is a strong connection between third-trimester pregnant women's iodine level and the length of the newborn [8] 
The Central Tapanuli Regency is divided into 20 districts, 159 villages and 56 sub-districts. According to the Food Security Agency's (2019) report, the Central Tapanuli Regency has a food security index score of 64.71. This score describes the availability, access, and usage of food in the Central Tapanuli Regency, including the fourth priority category classified as food secure districts, implying that food insecurity exists in the Central Tapanuli Regency [9], [10]. This can be seen from the report from the Food and Livestock Security Service of North Sumatra Province (2020) which noted that almost a third of the area or $35 \%$ of the districts in the Central Tapanuli Regency are food insecure [11].

Food insecurity can be found in various regions of the Central Tapanuli Regency based on household consumption and expenditure, with an average daily energy and protein consumption per capita of 2038.20 $\mathrm{kcal}$ and $53.99 \mathrm{~g}$ of protein. This number is still below the Ministry of Health's suggested nutritional adequacy rate of $2100 \mathrm{kcal}$ and $57 \mathrm{~g}$ of protein. Likewise, spending on food at the family level exceeds $65 \%$ of total expenditure $(66.56 \%)$, indicating that the majority of household spending is spent on food necessities [11]. According to the Food Security Agency, if a household's food expenditure exceeds $65 \%$, it is classified as food insecure, the higher the community's income, the lower the percentage of food expenditure [10].

Based on the background, the purpose of this study was to determine the relationship between household food security status and the nutritional status of pregnant women in the Central Tapanuli Regency.

\section{Methodology}

This research is part of the DRPM research project titled Improving the Nutrition of Pregnant Women and the Success of Breastfeeding Immediately After Birth in the Central Tapanuli Regency by Strengthening Family Food Security. This research design was a form of action research. The diagnostic action stage of this research was the stage in which the degree of household food security and the factors that influence and assess the nutritional status of pregnant women (CED, anemia, and IDDs were examined. Data were collected in eight districts of the Central Tapanuli Regency. Purposive sampling was used in this study, which included 131 pregnant women. This research has been declared ethically qualified with the number 403/KEP/USU/2021 from the Research Ethics Committee of the University of Sumatera Utara. Primary data were obtained from interviews using a questionnaire, whereas the secondary data were obtained from the Health Office of the Central Tapanuli Regency. The Maxwell method was used to determine household food security status (based on energy consumption and family food expenditure), while hemoglobin level testing with a digital measuring instrument (Easy Touch $\mathrm{GCH}$ ) was used to determine anemia status, and upper arm circumference (MUAC) was used to determine chronic energy deficiency status (CED). lodine levels in urine were measured at the Balai GAKI Magelang laboratory by sending 58 urine samples; however, only 32 samples were analyzed due to technical problems in delivering urine. Data were presented in the form of a distribution table of respondent characteristics, with a cross-tabulation of household food security status with anemia in pregnant women and CED status in pregnant women. Household food security status, anemia, and CED were presented as categorical data. The Chi-square statistical test was employed in the study to assess the significance of the connection between the two variables, with a value of $\alpha=0.05$.

\section{Results}

The characteristics of the respondents can be seen in Table 1 which consists of several variables, namely, the age of pregnant women, household income, and household food security status. Based on age, it is known that the most of the respondents are in the healthy reproductive age (20-35 years) which is as much as $84 \%$. Based on the history of formal education owned, the highest percentage was in pregnant women who

Table 1: Family characteristics of pregnant women

\begin{tabular}{|c|c|c|}
\hline Variable & $\mathrm{N}$ & $\%$ \\
\hline \multicolumn{3}{|l|}{ Respondent's age $(n=131)$} \\
\hline$\leq 19$ years old & 2 & 1.5 \\
\hline $20-35$ years old & 110 & 84 \\
\hline$>35$ years old & 19 & 14.5 \\
\hline \multicolumn{3}{|l|}{ Family income $(n=131)$} \\
\hline Meet the regional minimum wage & 31 & 23.7 \\
\hline Doesn't meet the regional minimum wage & 100 & 76.3 \\
\hline \multicolumn{3}{|l|}{ Educational background $(n=131)$} \\
\hline Graduated from elementary school & 25 & 19.1 \\
\hline Graduated from middle school & 37 & 28.2 \\
\hline Graduated from high school & 54 & 41.2 \\
\hline Graduated from college & 15 & 11.5 \\
\hline \multicolumn{3}{|l|}{ Respondents knowledge $(n=131)$} \\
\hline Adequate & 25 & 19.1 \\
\hline Less adequate & 106 & 80.9 \\
\hline \multicolumn{3}{|l|}{ Food security status $(n=131)$} \\
\hline Secure & 14 & 18.3 \\
\hline Insecure & 107 & 81.7 \\
\hline \multicolumn{3}{|l|}{ Nutritional status anemia $(n=131)$} \\
\hline Anemia & 73 & 58.7 \\
\hline Not anemia & 58 & 44.3 \\
\hline \multicolumn{3}{|l|}{ CED $(n=131)$} \\
\hline CED & 25 & 19.1 \\
\hline Not CED & 106 & 80.9 \\
\hline \multicolumn{3}{|l|}{ lodine levels in urine $(n=36)$} \\
\hline Low $(<150 \mu \mathrm{G} / \mathrm{L})$ & 23 & 63.9 \\
\hline Enough $(150-246 \mu \mathrm{G} / \mathrm{L})$ & 12 & 33.3 \\
\hline High $(>250 \mu \mathrm{G} / \mathrm{L})$ & 1 & 2.8 \\
\hline \multicolumn{3}{|c|}{ Nutritional intake of pregnant women $(n=131)$ energy } \\
\hline Adequate & 55 & 42 \\
\hline Less adequate & 76 & 58 \\
\hline \multicolumn{3}{|l|}{ Protein } \\
\hline Adequate & 51 & 38.9 \\
\hline Less adequate & 80 & 61.1 \\
\hline \multicolumn{3}{|l|}{ Iron (FE) } \\
\hline Adequate & 3 & 2.3 \\
\hline Less adequate & 128 & 97.7 \\
\hline \multicolumn{3}{|l|}{ Vitamin C } \\
\hline Adequate & 46 & 35.1 \\
\hline Less adequate & 85 & 64.9 \\
\hline
\end{tabular}


graduated from high school, namely, $41.2 \%$. Meanwhile, when viewed from the total household income, the most of the respondents $(76.3 \%)$ earn below the minimum wage in the Central Tapanuli Regency. The results showed that the intake of nutrients for pregnant women, including energy, protein, Vitamin $\mathrm{C}$, and iron (Fe) was mostly less than the recommended adequacy.

Food secure families tend to have sufficient energy consumption for pregnant women (95.8\%), but food insecure families tend to have less energy consumption for pregnant women $(70.1 \%)$, as seen in Table 2. According to the statistical analysis, there is a link between food security in the family and pregnant women's energy consumption $(p=0.000)$.

Table 2: Cross-tabulation of family food security status with energy intake of pregnant women

\begin{tabular}{|c|c|c|c|c|c|c|c|}
\hline \multirow[t]{3}{*}{ Food security status } & \multicolumn{4}{|c|}{$\begin{array}{l}\text { Energy intake of pregnant } \\
\text { women }\end{array}$} & \multirow{2}{*}{\multicolumn{2}{|c|}{ Total }} & \multirow[t]{3}{*}{ p-value } \\
\hline & \multicolumn{2}{|c|}{ Adequate } & \multicolumn{2}{|c|}{$\begin{array}{l}\text { Less } \\
\text { adequate }\end{array}$} & & & \\
\hline & $\mathrm{n}$ & $\%$ & $\mathrm{n}$ & $\%$ & $\bar{N}$ & 5 & \\
\hline Secure & 23 & 95.8 & 1 & 4.2 & 24 & 100 & 0.000 \\
\hline Insecure & 32 & 29.9 & 75 & 70.1 & 107 & 100 & \\
\hline
\end{tabular}

Food secure families tend to consume sufficient protein $(66.7 \%)$, and food insecure families tend to consume less protein $(67.3 \%)$, more details can be seen in Table 3 . There is a significant relationship ( $p=0.004$ ) between family food security status and protein consumption of pregnant women.

Table 3: Cross-tabulation of family food security status with protein intake of pregnant women

\begin{tabular}{|c|c|c|c|c|c|c|c|}
\hline \multirow[t]{3}{*}{ Food security status } & \multicolumn{4}{|c|}{$\begin{array}{l}\text { Protein intake of pregnant } \\
\text { women }\end{array}$} & \multirow{2}{*}{\multicolumn{2}{|c|}{ Total }} & \multirow[t]{3}{*}{ p-value } \\
\hline & \multicolumn{2}{|c|}{ Adequate } & \multicolumn{2}{|c|}{$\begin{array}{l}\text { Less } \\
\text { adequate }\end{array}$} & & & \\
\hline & $\mathrm{n}$ & $\%$ & $n$ & $\%$ & $\mathrm{~N}$ & $\%$ & \\
\hline Secure & 16 & 66.7 & 8 & 33.3 & 24 & 100 & 0.004 \\
\hline Insecure & 35 & 32.7 & 72 & 67.3 & 107 & 100 & \\
\hline
\end{tabular}

According to the results of the cross-tabulation in Table 4, it is known that from food secure families, the most of the pregnant women are not anemic $(58.3 \%)$ and the most of the food insecure mothers are anemic $(58.9 \%)$. This shows that there is a tendency that pregnant women who are in food insecure family conditions have the potential to experience anemia compared to those who are food secure (OR = 2.005), although statistically, the relationship between food security status and anemia of pregnant women is not significantly related $(p=0.134)$.

Table 4: Cross-tabulation of household food security status with anemia status of pregnant women in the Central Tapanuli Regency

\begin{tabular}{lllll}
\hline Food security status & \multicolumn{2}{l}{ Anemia status (\%) } & Total (\%) & p-value \\
\cline { 2 - 3 } & Not anemia & Anemia & & \\
\hline Secure & $14(58.3)$ & $10(41.7)$ & $24(100)$ & 0.172 \\
Insecure & $44(41.1)$ & $63(58.9)$ & $107(100)$ & \\
\hline
\end{tabular}

The proportion of pregnant women who do not have CED is greater in families who are food secure
$(91.7 \%)$, compared to families who are food insecure $(78.5 \%)$ as seen in Table 5 . This indicates that there is a tendency that pregnant women who are in food insecure family conditions have the potential to experience CED compared to those who are food secure (OR = 3,012), although statistically, the relationship between food security status and anemia of pregnant women is not significantly related $(p=0.163)$.

Table 5: Cross-tabulation of household food security status with ced status of pregnant women in the Central Tapanuli Regency

\begin{tabular}{lllll}
\hline Food security status & \multicolumn{2}{l}{ CED status $(\%)$} & Total $(\%)$ & p-value \\
\cline { 2 - 3 } & Not CED & CED & & \\
\hline Secure & $22(91.7)$ & $2(8.3)$ & $14(100)$ & 0.163 \\
Insecure & $84(78.5)$ & $23(21.5)$ & $107(100)$ & \\
\hline
\end{tabular}

\section{Discussion}

The results of this study indicate that the most $(81.7 \%)$ of the respondents are food insecure households. Table 1 states that more than half of the respondents have food insecure status (81.7\%). A household's food security can be influenced by several factors, especially food access which tends to be influenced by income, related to the proportion of expenditure on food from the total income owned. The results of research conducted by Nunnery et al. 2017 that low to very low levels of food security generally occurs in families of low-income pregnant women [12].

Based on the data that have been obtained, it shows that the income of the respondents is in the fairly low-income category (based on the regional minimum wage of the Central Tapanuli Regency) as much as $76.3 \%$. Household income is related to the ability to access food to meet nutritional needs, especially for certain food ingredients that have relatively high economic value such as animal protein [13]. Apart from the economic aspect, daily consumption patterns can also be influenced by insight or knowledge. Mothers who have good nutritional knowledge are more likely to consume a variety of foods compared to mothers who have low knowledge of food and nutrition [14]. The level of education of pregnant women can be used as an indicator to determine the acceptability of nutritional information that is possible to obtain during pregnancy [15]. According to the data obtained, the highest level of education is high school graduates $(41.2 \%)$, while the rest are university, elementary, and junior high school graduates so that it is classified as a high educational background. However, the level of knowledge of the respondents is mostly in the less category, therefore, the mother's income and knowledge can be taken into consideration in choosing the type of food to be consumed [15].

During pregnancy, maternal nutritional intake and nutritional status influence mother and newborn 
health. The adequacy of energy and protein nutrition is a major problem to sustain fetal growth and the metabolic functions of the body. The results revealed that the majority of pregnant women's energy and protein consumption is less than the required sufficiency, with $58 \%$ and $61.1 \%$, respectively. Poor maternal nutritional intake is a major predictor of intrauterine growth restriction and small neonate size, as well as an elevated risk of maternal and infant mortality and morbidity [16]. A total of $70.5 \%$ of pregnant women's energy nutrient intake is less than adequate for food insecure families, while $4.2 \%$ of pregnant women's nutritional intake is less than adequate for food secure families. Statistical analysis revealed a significant relationship $(p=0.000)$ between family food security and pregnant women's energy intake with $\mathrm{OR}=53.9$. Lack of protein intake was also seen to be associated with food insecure families $(67.3 \%)$, and statistical analysis revealed a significant relationship ( $p=0.0004$ ) between family food security status and pregnant women's protein intake $(O R=4.1)$. The results of the study are in line with the research conducted by Saaka et al. Food insecure pregnant women consumed fewer vegetables than vulnerable participants, according to the research on the types of food consumed by pregnant women in the past $24 \mathrm{~h}$, and there was a strong and significant negative relationship between consumption of animal products (eg., meat, chicken, and fish) in the past $24 \mathrm{~h}$ and food insecurity status [17]. Food security is the state in which all people have physical and economic access to sufficient food to fulfill their dietary needs to live a productive and healthy life [18].

Iron sources, both heme and non-heme, are required to fulfill the increased iron need during pregnancy from animal and plant diets. Furthermore, foods high in Vitamin $\mathrm{C}$ are beneficial for pregnant women to consume since they help with iron absorption. Foods or drinks containing tannins, such as tea and coffee, should also be avoided by pregnant women since they serve as inhibitors of iron absorption [19]. According to the study's results, pregnant women's intake of iron ( $\mathrm{Fe}$ ) and Vitamin $\mathrm{C}$ was generally in the lower range, at $64.9 \%$ and $97.7 \%$, respectively. In pregnant women, both of these micronutrients aid in the formation of hemoglobin. The iron content of meals is critical, especially for pregnant women, because the need for iron increases throughout pregnancy. Iron is also included in the special message of balanced nutrition as one of the key micronutrients during pregnancy. This is due to an increase in red blood cell mass and plasma volume, as well as preparation for iron loss during delivery [20].

Data on anemia status in respondents in this study were known through the measurement of hemoglobin levels of pregnant women. According to Table 1, there were 77 pregnant women with anemia $(58.7 \%)$. This shows that the most of the respondents experienced anemia during pregnancy. The high prevalence of anemia in pregnant women reflects various nutritional deficiencies. Socio-economic status, gestational age, low dietary diversity, low dietary quantity, and intake of iron supplements during pregnancy are risk factors for anemia [21]. Animal source foods offer good amounts of nutrients required by humans; around $40 \%$ of heme iron originates from animal foods, with a biological availability of approximately $23 \%$, allowing nutrients to be more easily absorbed and utilized by the body [22].

Long-term nutritional insufficiency leads pregnant women to develop CED, which can have an impact on the baby. Pregnant women with CED and nutritional anemia are 7 times more likely to have stunting children, 11 times more likely to have underweight children, and 12 times more likely to have wasting children than pregnant women with adequate nutritional status. According to the findings, there were 25 pregnant women $(19.1 \%)$ who had CED, and the proportion of pregnant women who had CED was higher in food insecure families, with as many as 23 pregnant women having CED. Statistical analysis revealed that there was no link between family food security and pregnant women's CED status ( $p=.163$ ). The relationship between household food security and CED status was not found. Hence, because the absence of a relationship between low CED and dietary variety does not correctly represent optimal energy intake, low dietary diversity does not influence CED [23]. In this case, food security has no direct impact on pregnant women's nutritional status; rather, food intake is a direct factor.

Pregnant women are the most vulnerable to iodine deficiency because the increased iodine need during pregnancy is not always matched by appropriate iodine intake. IDDs are all of the negative consequences of iodine deficiency on human growth and development that may be avoided by getting enough iodine. lodine deficiency is associated with various degrees of fetal brain damage and cretinism [24]. The study's results were derived from 36 urine samples of pregnant women who were analyzed and showed low levels of iodine in the urine of up to 23 pregnant women (63.9\%). In pregnant women, a lack of iodine intake from iodized salt might develop if salt consumption is $<10 \mathrm{~g}$ per person per day. According to the Saidin Mulyantoro's research results and the total diet study data, salt consumption per person per day ranges between 5.5 and $6.8 \mathrm{~g}$ [25], [26].

\section{Conclusions}

According to the study's findings, 14 families (18.3\%) were determined to be food secure, while 107 families $(81.7 \%)$ were deemed to be food insecure. 
Pregnant women with anemia had a nutritional status of $58.7 \%$, those with CED were $19.1 \%$, and pregnant women with the low iodine levels were $63.9 \%$. There is a link between family food security and pregnant women's energy intake $(p=0.000)$, as well as a relationship between family food security and pregnant women's protein intake $(p=0.004)$. Families that are food secure have the majority of their pregnant women who are not anemic (58.3\%), whereas families that are food insecure have the majority of their pregnant women who are anemic (58.9\%).

\section{References}

1. Rosso P. Nutrition and Metabolism in Pregnancy, Mother, and Fetus. New York: Oxford University Press; 1990. p. 324.

2. World Health Organization. Promoting Optimal Fetal Development: Report of a Technical Consultation Nutrition. Geneva, Switzerland: World Health Organization; 2003.

3. Badan Perencananaan Pembangunan Nasional (Bappenas). Kerangka Kebijakan Gerakan Sadar Gizi Dalam Rangka Seribu Hari Pertama Kehidupan (1000 HPK). Jakarta: Badan Perencananaan Pembangunan Nasional; 2012.

4. World Health Organization. WHO Recommendations on Antenatal Care for A Positive Pregnancy Experience. Geneva: World Health Organization Press; 2016. p. 14-40.

5. Ravishankar KA. Influence of mothers' chronic energy deficiency on the nutritional status of preschool children in empowered action group states in India. Int $\mathrm{J}$ Nutr Pharmacol Neurol Dis. 2012;2(3):198-209.

6. Iddowu OS, IbiYemi OO, Wasiu AA, Olayinka CS. Maternal and child under-nutrition in rural and urban communities of Lagos state, Nigeria: The relationship and risk factors. BMC Res Notes. 2013;6:286. https://doi.org/10.1186/1756-0500-6-286 PMid:23880121

7. Yunita HS, Rahayuning PD, Apoina K. Anemia dan kek pada ibu hamil sebagai faktor risiko kejadian bayi berat lahir rendah (BBLR) (studi di wilayah kerja puskesmas Juwana Kabupaten pati). J Kesehat Masy. 2019;7(1):322-9.

8. Pibriyanti K, SS D, Pemayun TG. Hubungan status iodium ibu hamil trimester III dengan status iodium dan nilai antropometri bayi baru lahir di daerah GAKI. J Gizi Indones. 2017;5(2):75-81. https://doi.org/10.14710/jgi.5.2.75-81

9. Badan Ketahanan Pangan. Indeks Ketahanan Pangan. Jakarta: Badan Ketahanan Pangan; 2018.

10. Badan Ketahanan Pangan. Indeks Ketahanan Pangan Indonesia 2019. Badan Ketahanan Pangan Kementrian Pertanian. Jakarta: Badan Ketahanan Pangan; 2019. Available from: http://www.bkp.pertanian.go.id/storage/app/media/Bahan 2020/IKP2019FINAL.pdf

11. Dinas Ketahanan Pangan dan Peternakan. Peta Ketahanan dan Kerentanan Pangan (Food Security and Vulnerability Atlas) Provinsi Sumatera Utara Tahun 2020. Medan: Dinas Ketahanan Pangan dan Peternakan; 2020.

12. Nunnery DL, Labban JD, Dharod JM. Interrelationship between food security status, home availability of variety of fruits and vegetables and their dietary intake among low-income pregnant women. 2017;21(4):807-15. https://doi.org/10.1017/

\section{S1368980017003032}

PMid:29125093

13. Suryanty M, Reswita R. Analisis konsumsi pangan berbasis protein hewani di kabupaten lebong: Pendekatan model aids (almost ideal demand system). J AGRISEP. 2016;15(1):101-10.

14. Segaye D, Tamiru D, Belachew T. Factors associated with dietary practice and nutritional status of pregnant women in rural communities of illu aba bor zone, Southwest. Nutr Diet Suppl. 2020;12:103-12.

15. Kusuma R, Khomsan A, Kustiyah L. Konsumsi ikan pada ibu hamil dan kaitannya dengan outcome kelahiran. Media Kesehat Masy Indones. 2017;13(4):295.

16. Hjertholm KG, Holmboe-Ottesen G, Iversen PO, Mdala I, Munthali A, Maleta K, et al. Seasonality in associations between dietary diversity scores and nutrient adequacy ratios among pregnant women in rural Malawi-a cross-sectional study. Food Nutr Res. 2019;63(2712):1-8. https://doi.org/10.29219/fnr. v63.2712 PMid:30837821

17. Saaka M, Oladele J, Larbi A, Hoeschle ZI. Household food insecurity, coping strategies, and nutritional status of pregnant women in rural areas of Northern Ghana. Food Sci Nutr. 2017;5(6):1154-62. https://doi.org/10.1002/fsn3.506 PMid:29188043

18. Binte N, Id A, Tahsina T, Hoque DE. Association of food security and other socio- economic factors with dietary diversity and nutritional statuses of children aged 6-59 months in rural Bangladesh. PLoS One. 2019;14(8):e0221929. https://doi. org/10.1371/journal.pone.0221929

PMid:31465509

19. Pratiwi R, Widari D. Hubungan konsumsi sumber pangan enhancer dan inhibitor zat besi dengan kejadian anemia pada ibu hamil. Amerta Nutr. 2018;2(3):283.

20. Suryanarayana R, Santhuram A, Chandrappa M, Shivajirao $P$, Rangappa S. Prevalence of anemia among pregnant women in rural population of Kolar district. Int J Med Sci Public Health. 2016;5(3):454.

21. Berhe B, Mardu F, Legese H, Gebrewahd A, Gebremariam G, Tesfay K, et al. Prevalence of anemia and associated factors among pregnant women in Adigrat General Hospital, Tigrai, northern Ethiopia, 2018. BMC Res Notes. 2019;12(1):1-6. https://doi.org/10.1186/s13104-019-4347-4

PMid:31151463

22. Diana R, Khomsan A, Anwar F, Christianti DF, Kusuma R, Rachmayanti RD. Dietary quantity and diversity among anemic pregnant women in Madura Island, Indonesia. J Nutr Metab. 2019;2019:2647230.

23. Gosh S, Spielman K, Kershaw M, Ayele K, Kidane Y, Zillmer K, et al. Factors associated with mid-upper arm circumference as a measure of nutritional status in pregnant Ethiopian women : Implications for programming in the first 1000 days. PLoS One. 2019;26:1-15. https://doi.org/10.1371/journal.pone.0214358 PMid:30913234

24. World Health Organization. Assessment of lodine Deficiency Disorders and Monitoring Their Elimination, a Guide for Program Managers. $3^{\text {rd }}$ ed. Genewa: World Health Organization; 2007.

25. Mulyantoro DK. Perlukah wanita hamil mendapat suplementasi iodium? Media Gizi Mikro Indones. 2017;8(2):137-50.

26. Mulyantoro DK, Hakimi M, Basuki E. Hubungan kadar iodium dalam garam beriodium di rumah tangga dengan kecukupan iodium berdasarkan nilai ekskresi iodium urin (EIU) pada wanita usia Subur. Media Gizi Mikro Indones. 2013;5(1):41-52. 